УДК 792.8:7.071.2

DOI: $10.31866 / 2616-7646.2 .1 .2019 .172180$

\title{
ТВОРЧЕ КРЕДО С. ЛИФАРЯ ТА ЙОГО ВНЕСОК У РОЗВИТОК ТЕОРІЇ ТАНЦЮ
}

\author{
Чепалов Олександр Іванович, \\ доктор мистецтвознавства, професор, \\ Київський національний університет культури і мистецтв, \\ Київ, Україна, \\ https://orcid.org/0000-0002-2033-357X, \\ chepalovstagmail.com
}

Мета дослідження - виявити сучасні аспекти цінності теоретичних положень Лифаря у світлі актуальних понять теорії танцю і її практичних (творчих) виявів. Методологія. Використання історичного методу уможливило пошук відповідної проекції на теоретичні висновки Лифаря в часи, коли теорією танцю фактично не переймався жоден дослідник хореографічного мистецтва. Компаративний метод дав змогу зрозуміти відповідність низки явищ естетиці балетного мистецтва та композиції балетної вистави, що мають адекватний відгук у хореографічному мистецтві XX - початку XXI ст. Наукова новизна. Здійснено спробу абстрагуватися від домінуючих у сучасній літературі біографічно-ениклопедичних досліджень творчої особистості Лифаря та зосередитись на тих проблемах, які були характерними під час пошуків нової хореографічної мови в першій половині XX ст., аби пов'язати їх з народженням хореології як самостійної науки. Висновки. У теоретичних позиціях С. Лифаря, а також у наочних результатах його творчої практики спостерігають істотні невідповідності, що $є$ наслідком реальних протиріч техніки танцю 3 його внутрішньою сутністю, а також з надмірною захопленістю хореографа, який не завжди міг адекватно осягнути цінність свого доробку. Важливо, що Лифар, зайнявши важливе місце в низці знакових теоретиків танцю, переймається не лише класикою, але й створенням нових рухів, спроможних виражати абстрактні ідеї, нормалізувати в теорії танцю деякі метафізичні поняття. Джерелом пошуку таких рухів Лифар вбачає саме в тілі людини, яке нагороджує iіï вищою насолодою, що народжується з тілесної гармонії руху, і називає поняття краси об'єднуючим виражальні можливості тіла, котре обожнює як балетмейстер і танцівник. Ці та деякі інші положення теоретичних праць Лифаря гармонійно вписуються в доробок видатних дослідників танцю і стимулюють студіювання його теоретичних підвалин.

Ключові слова: Лифар Серж; балет; хореографія; хореоавтор; «Російські сезони» С. Дягілєва. 


\section{ТВОРЧЕСКОЕ КРЕДО С. ЛИФАРЯ И ЕГО ВКЛАД В РАЗВИТИЕ ТЕОРИИ ТАНЦА}

\author{
Чепалов Александр Иванович, \\ доктор искусствоведения, профессор, \\ Киевский национальный университет \\ культуры и искусств, \\ Киев, Украина, \\ https://orcid.org/0000-0002-2033-357X, \\ chepalovstagmail.com
}

Цель исследования - выявить современные аспекты ценности теоретических положений Лифаря в свете актуальных понятий теории танца и ее практических (творческих) проявлений. Методология. Использование исторического метода сделала возможным поиск соответствующей проекции на теоретические выводы Лифаря во времена, когда теорией танца фактически не занимался ни один исследователь хореографического искусства. Компаративный метод позволил понять соответствие ряда явлений эстетике балетного искусства и композиции балетного спектакля, имеющих адекватный отклик в хореографическом искусстве XX - начала XXI в. Научная новизна. Сделана попытка абстрагироваться от преобладающих в современной литературе биографически-эниклопедических исследований личности Лифаря и сосредоточиться на тех проблемах, которые были характерны во время поисков нового хореографического языка в первой половине XX в., чтобы связать их с рождением хореологии как самостоятельной науки. Выводы. В теоретических позициях С. Лифаря, а также в наглядных результатах его творческой практики наблюдаются существенные несоответствия. Это является следствием реальных противоречий техники танца с его внутренней сущностью, а также с избыточным увлеченностью хореографа, который не всегда мог адекватно понять ценность своего репертуара. Важно, что Лифарь, заняв важное место в ряду знаковых теоретиков танца, проникается не только классикой, но и созданием новых движений, которые способны выра-

\section{SERGE LIFAR'S CREATIVE CREDO AND HIS CONTRIBUTION TO THE THEORY DANCE}

\author{
Oleksandr Chepalov, \\ Ph.D. (Doctor of Arts), professor, \\ Kyiv National University \\ of Culture and Arts, \\ Kyiv, Ukraine, \\ https://orcid.org/0000-0002-2033-357X \\ chepalovstagmail.com
}

The purpose of the article is to reveal the modern aspects of Lifar's theoretical thesis value in the light of current concepts of the dancing theory and its practical (creative) manifestations. Methodology. The use of the historical method made it possible to search for the corresponding projection on the Lifar's theoretical conclusions at a time when there is not a single researcher of choreographic art actually engaged in the dancing theory. The comparative method made it possible to understand the correspondence of a number of phenomena to the aesthetics of ballet art and the composition of a ballet performance, which have an adequate response in the choreographic art of the 20th - early 21st centuries. Scientific novelty. An attempt has been made to abstract from Lifar's biographical and eniclopedic studies of the Lifar's personality and to focus on the problems that were characteristic during the search for a new choreographic language in the first half of the twentieth century, in order to link them with the birth of choreology as an independent science. Conclusions. In the S. Lifar's theoretical thesis, as well as in the visual results of his creative practice, there are significant discrepancies. This is a consequence of the real contradictions of the dance technique with its inner essence, as well as with the excessive choreographer's enthusiasm, who could not always adequately understand the value of his repertoire. It is important that Lifar is taking an important place in the series of iconic dance theorists and it is penetrated not only by the classics, but also by the creation of new movements that are able to express abstract ideas and normalize some metaphysical concepts in the dancing theory. 
жать абстрактные идеи, нормализовать в теории танца некоторые метафизические понятия. Источник поиска таких движений Лифарь усматривает именно в теле человека, которое награждает его высшим наслаждением, что рождается из телесной гармонии движения, и называет понятие красоты объединяющим выразительные возможности тела, которое обожает как балетмейстер и танцовщик. Эти и некоторые другие положения теоретических трудов Лифаря гармонично вписываются в наследие выдающихся исследователей танца и стимулируют изучение его теоретических основ.

Ключевые слова: Лифарь Серж; балет; хореография; хореоавтор; «Русские сезоны» С. Дягилева.
The source of the search for such movements Lifar sees it in the human body, which rewards him with the highest pleasure that comes from bodily harmony of movement, and calls the concept of beauty unifying the body's expressive possibilities, which he adores as a choreographer and dancer. These and some other thesis of Lifar's theoretical works of harmoniously fit into the legacy of outstanding dance researchers and stimulate the study of its theoretical foundations.

Keywords: Serzh Lifar; ballet; choreography; choreographer; "Russian Seasons" S. Dyagilev.

Актуальність теми дослідження. Попри те, що про творчу особистість Лифаря існує багато наукової, біографічної та публіцистичної літератури, у тому числі мемуаристики, його внесок у теорію танцю малодосліджений і повною мірою не оцінений. Ставлення Лифаря до танцю відбите в його мемуарах про С. Дягілєва, автобіографічних творах «Важкі роки» (1934) (Лифарь, 1994), а також у спогадах «Мемуари Ікара» (1983) (Лифарь, 1995), виданих українською мовою в 2007 році (Лифар, 2007), де він намагався пояснити достеменні причини власних вчинків у суспільно-політичному й підкреслити свій особистий внесок у теорію та історію хореографічного мистецтва. С. Лифар у спогадах «Мемуари Ікара» (Лифарь, 1995, глава «Хореологія») наголошує на тому, що мова танцю - це «мова абстракції, рівноправна з музичною мовою», а «“хореавтор” такий само творець, як поет, музикант, скульптор, архітектор або живописець» (Лифарь, 1995, с. 228). Незважаючи на те, що думки Лифаря щодо виділення хореологї̈ в окрему науково-практичну галузь є цілком слушними, це визначення не знайшло у фахівців танцю практичного застосування, а важливі теоретичні питання цього мистецького жанру - такі, як закони інтерпретації хореографічного тексту, його когнітивна структура й чуттєво-емпіричний зміст взагалі не знаходять розв’язання.

Аналіз останніх досліджень і публікацій. 3 початку XXI ст. у науковій літературі з'явилося кілька аналітичних робіт, створених не за шаблонами ециклопедично-довідкових видань. Вони розкривають суттєві риси творчості Лифаря як митця й теоретика хореографічного мистецтва. Це, насамперед, статті української дослідниці О. Зінич, яка аналізує пластичні виміри хореографічного мистецтва в їхній безпосередній залежності від пластичності музичної мови. Зокрема, у роботі «Мова пластики в сучасному французькому балетному (пластичному) театрі: метаморфози форм руху» міститься аналіз форм пластичного руху крізь призму різних напрямів французького танцювального мистецтва XX-XXI ст. - від естетики мюзик-хольного балету до новітніх постмодерністських танцювальних систем (Зінич, 2009). 
Принципове значення для осягнення творчої спадщини Лифаря в соціально-історичному аспекті має стаття Т. Апанасенко «Теорія С. Лифаря як синтез концепцій масового та елітарного мистецтва» (Апанасенко, 2014). Але відкритою залишається проблема виявлення відповідності теоретичних положень Лифаря його практичному доробку.

Мета дослідження - виявити сучасні аспекти цінності теоретичних положень Лифаря у світлі актуальних понять теорії танцю і їі практичних (творчих) виявів.

Виклад основного матеріалу. У статті Т. Апанасенко «Теорія С. Лифаря як синтез концепцій масового та елітарного мистецтва» подається аналіз концепцій, побудованих на суб'єктно-об’єктному і суб’єктно-суб'єктному ставленні до глядача, аналізуються перспективи мистецтва, натхненного однією з установок стосовно ставлення до глядача, а саме з точки зору його соціальної ролі і здатності до самодостатнього розвитку. Теорія хореографічного мистецтва С. Лифаря розглядається Т. Апанасенко як така, що знімає протиріччя обох концепцій, хоча насправді художні вподобання митця тяжіли саме до елітарного мистецтва. «Рисою прогресу в мистецтві і гуманізації мистецтва, - зазначаєдослідниця, оголошується свобода глядача від нав'язування йому з боку творця художнього твору якихось емоційних та інтелектуальних реакцій. Це припускає відсутність однозначного трактування сенсу твору, співавторство творця і глядача в створенні цього сенсу» (Апанасенко, 2014, с. 20). («Трактат про хореографію» С. Лифаря цитується, як вказано у статті Т. Апанасенко, у перекладі О. Я. Васильєвої - О.Ч.).

Т. Апанасенко вважає, що «сенсів у художнього твору будь-якого жанру може виявитися стільки, скільки разів твір сприйматиметься окремими індивідуумами, бо когнітивне розуміння одного й того ж витвору мистецтва неповторне і в різних людей, і в однієї й тієї ж людини в різний час. У всіх цих індивідуальних випадках має місце співавторство автора художнього твору та його споживача, що надає сприймаючій стороні більшої творчої свободи, а творець, своєю чергою, змушений уникати всього, що дає привід для однозначного трактування» (Апанасенко, 2014, с. 19).

T. Апанасенко бачить шлях до зняття цього протиріччя в постулатах теорії хореографічного мистецтва С. Лифаря. На думку балетмейстера, «сутність хореографії в тому, аби віднайти... необхідний жест, спосіб пластичного вираження емоціï» (Lifar, 1952, с. 107). Адже «танець може виражати лише емоції в чистому стані, відокремлені від часу й простору, емоції-категорії у своєму роді. Викликаний до життя емоцією творця естетичний феномен стає визначальним, і тоді настає момент, коли творець бачить в естетичному феномені повну ілюстрацію того, що він пережив» (Lifar, 1952, с. 110).

Отже, згідно 3 Лифарем, «естетичний феномен $є$ еквівалентом емоційного аналогу повсякденного життя, часто красивішого та піднесенішого» (Lifar, 1952, с. 109). Лифар пише: «Я нічого не ілюструю. Якщо відняти в глядача лібрето мого балету (це лібрето цілком можна вмістити в одне слово - назву), він не дізнається, що саме я хотів проілюструвати, якщо не скористається тим, що лежить за межами засобів виражальності цього мистецтва, тобто підказкою у вигляді лібрето» (Lifar, 1952, с. 110).

Отже, єдина можливість комунікації між автором і глядачем, відповідно до теорії Лифаря, - «спосіб, заснований на викликанні в глядача потрібної емоції 
(передбачається, що вона співпадає з емоцією творця)» (Lifar, 1952, с. 109). Тривалий час С. Лифар перебував під впливом естетичних і художніх смаків свого метра й наставника С. Дягілєва (1872-1929). Водночас балетмейстер використовував творчий досвід таких законодавців сучасного йому мистецтва, як Поль Валері (1871-1945) та Ж. Кокто (1889-1963), які, своєю чергою, дуже високо поціновували талант Лифаря-хореографа та його художній смак.

Зокрема Кокто (як і Лифар, член Інституту Франції), один $з$ авторів балету «Парад» (1917), твору, що проголосив революцію в галузі видовищних мистецтв, вбачав у фігурі Лифаря «спадкоємця слави Новера, Вестріса та Фокіна» (Батенина, 2005, с. 118).

Непослідовність, вільна асоціативність лідера французького модернізму, його схильність до поетичних алегорій і створення нових міфологем (згадати хоча б кінострічки про Орфея в 1949 і 1960 р.) відчуваються і в творах Лифаря, що по-новому тлумачать античні міфи й сюжети класичної драматургії. Кокто оформив як художник балет Лифаря «Федра» за мотивами Ж. Кокто.

До початку 1940-х років відносяться дві хореопоеми за творами П. Валері «Кроки» $\mathrm{i}$ «Небо під дахом». Лифарю була близькою думка цього поета про те, що «наше тіло має досить влади аби однією своєю силою, своїм рухом змінити природу речей так глибоко як це не пощастить зробити духу в його умоглядностях і мріях. Тіло танцівника, - розвиває цю тезу Лифар, - цей союз емоції і геометрії, завдяки своїм діям стає досконалим художнім інструментом: воно творить» (Лифарь, 1995, с. 260). Лифар посилається на відому думку Новера про наявність у балетах «механічного» складника танцю, який не хвилює, «якщо не керується розумом і не підказаний талантом, тобто коли в ньому немає “почуття й виражальності” (Лифарь, 1995, с. 145). Проте в теоретичних розшуках і практичній реалізації творчих намагань Лифаря $є$ багато невідповідностей. Коротко зупинимося на них і почнемо з балету «Сюїта в білому», який, по суті, є словником академічного танцю. «Деякі рухи виходять 3 моди та зникають, інші стають більш переважними і частіше вживаються залежно від часу та смаків балетмейстера. Цей спектакль, - зазначає в передмові до постановки балету Лифар, - є підсумком технічної еволюції танцю, котрий я постійно намагався збагачувати новими рухами та сучасним ставленням до них» (Лифарь, 1995, с. 145).

Для постановки цього балету на одну дію в Гранд-опера у 1943 р. Лифар пристосував партитуру французького композитора іспанського походження Едуарда Лало (1823-1892) з його балету «Намуна» на сюжет А. Мюссе. У 1882 р. «Намуну» поставив у Гранд-опера Люсьєн Петіпа, у 1908 р. балет було відновлено Л. Статсом. Лифар обрав для своєї композиції десять музичних номерів із партитури «Намуни», найбільш танцювальних, захоплюючих своїм іспанським колоритом та життєрадісними ритмами: «Сієста», «Тема з варіаціями», «Серенада», «Престо», «Мазурка», «Вальс цигарки», «Адажіо», «Флейта», «Фуете», «Манеж».

У послідовності ці сольні, дуетні та масові епізоди справді сприймаються як парад танцювальних форм кінця X1X ст., до яких Лифар іноді ставиться з легкою іронією. Його композиції притаманна танцювальна насиченість, задерикуватість у сполученні з ліризмом, уміле протиставлення й контрастні перебудови танцювальних груп. 
Усі балерини у виставі Лифаря одягнені в білі тюники, танцівники - у чорне трико та легкі білі сорочки, що, можливо, й викликало перейменування назви балету на «Чорне та біле» у відновленні 1977 р. Лифар побудував хореографічну композицію на двох паралельних площинах - на планшеті сцени та на помості ар'єрсцени з боковими сходинами. Геометричність побудови відчувалась і в побудові танців. В. Красовська помітила, що чисто академічна техніка «Сюїти в білому» «збагачена арабесками із зміщеним центром: виконувані за підтримки партнера, такі арабески танцівниць подовжують горизонтальну лінію пози. При цьому різноманітність дрібних заносок, виразність пальцевої техніки, ланцюжки обертань, що передаються одне одному та обплітають у всіх напрямках сцену, якомога краще відображають блискучу та елегантну дансантність музики Лало». Виражальність класичного танцю в цьому балеті В. Красовська називає не «образотворчою», а «інструментальною», підтверджуючи, що саме в цьому балеті Лифар «продовжив традиції симфонічного танцю» (Красовская, 1967, с. 183).

«Сюїта в білому» у постановці Гранд-опера була показана в СРСР двічі $(1958,1969)$, а також на гастролях Софійської опери в 1981 р. разом з балетом «Ромео і Джульєтта» на музику П. Чайковського та «Федрою» Ж. Оріка. У 1987 р. «Сюїту» виконали танцівники трупи із французького міста Нансі. Саме тоді В. Гаєвський помітив, що поряд з молодими балетмейстерами (Кіліан, Ноймайєр, ван Манен) Лифар виглядає «по-старомодному церемонним і трішечки простодушним» (Гаевский, 1981, с. 161). Дійсно, через багато років виявилось, що естетизуючи жанр балетної гала-вистави, переробляючи ї̈ на обряд показу класичного танцю, Лифар багато втратив у образному відтворенні музики.

«Танцівники трупи Нансі, - зазначає Гаєвський, - добре відчувають приховані іспанські ритми партитури, яка спонукає до жвавої танцювальної гри. Проте рух, ледве одержавши силу, застигає в царстві холодних чудових форм, де не дозволена будь-яка надмірність» (Гаевский, 1981, с. 161). 3 цього критик і робить висновок, що балет, замислений Лифарем «як маніфест неокласицизму (курсив наш. - О.Ч.), сьогодні має архаїчний вигляд. Адже після Баланчіна ніхто не сперечається з музикою, а після Фокіна ніхто не будує мізансцени так симетрично» (Гаевский, 1981, с. 162).

Порівняння з Фокіним та Баланчіним, активними співавторами дягілєвського репертуару, було не випадковим. I не тільки в контексті створення зразків симфонічного танцю. Фокін, наприклад, у своїй книзі «Проти течії», різко критикує Лифаря за довільний тон в описанні приватних деталей життя Дягілєва в біографічній книзі про організатора «Російських сезонів» (1939) та істотні невідповідності в теоретичному трактаті Лифаря «Танець» (1938), які, на думку Фокіна, «пов’язані 3 перебільшенням Лифарем власної ролі в мистецтві» (Фокин, 1981, с. 367).

Різке охолодження взаємин між Лифарем та Баланчіним з ініціативи останнього відбулося в 1979 р., про що свідчить сам Лифар у «Мемуарах Ікара». Думка Баланчіна з цього приводу неоприлюднена, проте показово, що у своїй книзі, написаній у співавторстві з Ф. Мейсон «101 stories of the Great ballets» («Сто одна розповідь про великий балет») (останнє американське видання 1975 р.), немає жодної згадки про балети Лифаря, навіть такі знані, як «Ікар» або «Міражі». Сам Лифар згадується тільки як виконавець головних ролей у балетах «Блудний син» 
С. Прокоф’єва та «Аполон Мусагет» І. Стравінського, які Д. Баланчін поставив наприкінці 1920-х років (Баланчин \& Мэйсон, 2000, с. 36).

Лифар наполягав, що саме він увів до наукового обігу термін «неокласика» стосовно техніки й естетики танцю і вів відлік своєї реформи танцю саме із прем'єри балету «Ікар» у 1935 р. (Лифар, 1995, с. 134), хоча таким правом, безумовно, користується Баланчін з часу постановки неокласичного опусу Стравінського «Аполон Мусагет» у 1928 p.

Аналізуючи хореографічну мову Лифаря, автор фундаментального дослідження «Балет і драма» П. Карп писав, що «танець у деяких його балетах - швидше мова абстракцій, ніж почуттів. Безпосередність у ньому зникає, комбінації, пози й рухи потребують розсудливого розшифрування. Складний танцювальний малюнок у різних ситуаціях служить різним цілям, але дуже рідко - висловлюванню переживань» (Карп, 1967, с. 194).

Карп робить висновок: «Лифар прагне здолати рамки хореографії, надати їй загальну значущість. Але робить це не стільки завдяки самій хореографії, скільки побічними засобами» (Карп, 1967, с. 183). Розглядаючи сюжетно-тематичні балети Лифаря, за усталеною ще з часів Новера термінологією - «балети-п’єси», Карп вбачає в них «символ віри» балетмейстера, який, не замислюючись, уподібнює мову хореографічну мові словесній. «У його балетах, - підкреслює дослідник, - герої та героїні обдаровані нескінченно тривалими варіаціями й монологами, адажіо виявляються хореографічними діалогами з безкрайніми варіаціонними частинами. Ці монологи й діалоги, не зібрані в композиційну єдність із хореографічною партитурою, кажучи просто, проходять повз свідомість, розпорошуючи яскраве враження, яке бодай захопило нас у перші миті вистави» (Карп, 1967, с. 183).

Дійсно, виникає враження, що зміст у Лифаря більше виголошується, ніж існує насправді. Балетмейстер часом дуже розумно й талановито вносить у свої балети пластичні образи дійсності, що самі по собі вражають, але насправді не стають основою танцю, не насичують його кордебалетні композиції, бо кордебалет для Лифаря - лише тло, лише супровід, якому віддається більше або менше місця. «Чим складніший зміст, - робить парадоксальний висновок Карп, - тим менше міститься в ньому танцю. Зміст його балетів швидше раціонально осягається, ніж емоційно сприймається» (Карп, 1967, с. 184).

Останнім часом вийшло чимало видань, що дають змогу максимально об’єктивізувати відомості про С. Лифаря. Головне місце серед них посідає книга швейцарського мистецтвознавця Ж.-П. Пасторі «Серж Лифар. Красота від диявола» (перше видання - Лозанна, 2009), назва якої певним чином протиставлена іншому визначенню митця як людини «нестерпної краси» (Пастори, 2013).

Книга Пасторі вирізняється 3-поміж багатьох аналогічних видань точними посиланнями та науковою доказовістю. У ній ідеться також про авторство численних книг, на обкладинках яких автором позначено С. Лифаря. Зокрема, у роботі Пасторі стверджується, що для кількох з них анонімно «позичав» Лифарю своє перо відомий на той час пушкініст Модест Гофман, а також його син Мішель Ростислав і навіть його діти (онуки Гофмана-старшого). Зокрема, для Лифаря Модест Гофман написав такі роботи, як «Танець» (1937), «Сергій Дягілєв» (1939) та «Історія російського балету» (1940-1945). Вони спочатку вийшли російською мовою, пізніше були перекладені французькою. Пасторі просить читачів книги «Важкі 
роки» («Страдные годы», 1935) поставитись обачливо до її змісту, оскільки майже всі її твердження побудовані на словах самого Лифаря, до того ж у книзі багато особистих спогадів М. Гофмана, який під час громадянської війни переховувався в Чернігові.

Від 1940-х років С. Лифар розраховував, за свідченням Пасторі, саме на допомогу Мішеля Ростислава, який виступив укладачем біографії Карлотти Грізі (1941), «Книги про балет» (1954), «Трьох грацій XX ст.». У вдячності за допомогу в створенні книги «Огюст Вестріс - бог танцю» Лифар згадує також Ніну Гофман, покійну дружину Мішеля Ростислава. Проте між замовником та виконавцем виникли суперечки, і тому за допомогою в написанні об'ємної біографії «Моє життя» (1965) Лифар звернувся до іншого літератора (Пастори, 2013, с. 80).

Наукова новизна. У статті здійснено спробу абстрагуватися від переважаючих у сучасній літературі біографічно-ениклопедичних досліджень творчої особистості С. Лифаря, сконцентрувавшись на тих проблемах, які були характерними під час пошуків нової хореографічної мови в першій половині XX ст., аби пов'язати їх з народженням хореології як самостійної науки.

Висновки. Незважаючи на наявність значної кількості видань про С. Лифаря, а також книг самого митця, що передані його вдовою до українських бібліотечних фондів та музеїв, до наукової визначеності спадщини видатного хореографа нашим дослідникам належить зробити багато кроків. Насамперед потрібно простежити закономірність звернення Лифаря до сюжетів та образної системи балетів у контексті естетичних вимог літератури і сучасного йому мистецтва. Треба враховувати, що в теоретичних позиціях митця, а також у наочних результатах його творчої практики існують істотні невідповідності, котрі $є$ наслідком реальних протиріч техніки танцю із його внутрішньою сутністю, а також з надмірною захопленістю хореографа, який не завжди міг адекватно осягнути цінність свого доробку.

Важливим є усвідомлення того, що С. Лифар, зайнявши важливе місце в низці знакових теоретиків танцю, переймався не тільки класикою, але й створенням нових рухів, спроможних виражати абстрактні ідеї, нормалізувати в теорії танцю деякі метафізичні поняття. Джерело пошуку таких рухів С. Лифар вбачав саме в тілі людини, яке нагороджує її вищою насолодою, що народжується з тілесної гармонії руху, і вважав поняття краси об'єднуючим виражальні можливості тіла, котре обожнював як балетмейстер і танцівник. Ці та деякі інші положення теоретичних праць С. Лифаря гармонійно вписуються в доробок видатних дослідників танцю і стимулюють студіювання його теоретичних підвалин.

\section{СПИСОК БІБЛІОГРАФІЧНИХ ПОСИЛАНЬ}

Апанасенко, Т.Е. (2014). Теория С. Лифаря как синтез концепций массового и элитарного искусства. Вестник Академии Русского балета им. А. Я. Вагановой, 35(6), 19-30.

Баланчин, Д., \& Мэйсон, Ф. (2000). 101 рассказ о большом балете (У. Сапцина, пер.). Москва: Крон-Пресс.

Батенина, Е. (2005). Сергей Лифарь - наш соотечественник. Обсерватория культуры, 3, 116-120.

Гаевский, В. (1981). Дивертисмент: Судьбы классического балета. Москва: Искусство. 
Зінич, О. (2009). Мова пластики в сучасному французькому балетному (пластичному) театрі: метаморфози форм руху. Студії мистецтвознавчі, 4(28), 80-89 [in Ukrainian].

Зінич, О. (2013). Серж Лифар - хореограф і хореолог: аспекти взаємодії музики і танцю. Студії мистецтвознавчі, 3/4, 127-136 [in Ukrainian].

Карп, П. (1967). О балете. Москва: Искусство.

Красовская, В. (1967). Статьи о балете. Ленинград: Искусство.

Лифар, С. (2007). Спогади Ікара. Київ: Пульсари.

Лифарь, С. (1994). Страдные годы. С Дягилевым. Воспоминания. Киев: Муза.

Лифарь, С. (1995). Мемуары Икара. Москва: Искусство.

Пастори, Ж.-П. (2013). Серж Лифарь. Красота от дьявола. Пермь: Книжный мир.

Фокин, М. (1981). Против течения: Воспоминания балетмейстера (2-е изд.). Ленинград: Искусство.

Lifar, S. (1952). Traité de chorégraphie. Paris: Bordas.

\section{REFERENCES}

Apanasenko, T.E. (2014). Teoriia S. Lifaria kak sintez kontceptcii massovogo i elitarnogo iskusstva [Theory S. Lifar as a synthesis of mass and elite art concepts]. Vestnik Akademii Russkogo baleta im. A. Ia. Vaganovoi, 35(6), 19-30 [in Russian].

Balanchin, D., \& Meison, F. (2000). 101 Stories of the Great Ballets. (U. Saptcina, Trans.). Moscow: Kron-Press [in Russian].

Batenina, E. (2005). Sergei Lifar - nash sootechestvennik [Sergey Lifar is our compatriot]. Observatoriia kultury, 3, 116-120 [in Russian].

Fokin, M. (1981). Protiv techeniia: Vospominaniia baletmeistera [Against the Current: Memories of the Choreographer] ( $2^{\text {nd }}$ ed.). Leningrad: Iskusstvo [in Russian].

Gaevskii, V. (1981). Divertisment: Sudby klassicheskogo baleta [Divertissement: The fate of classical ballet]. Moscow: Iskusstvo [in Russian].

Karp, P. (1967). O balete [About ballet]. Moscow: Iskusstvo [in Russian].

Krasovskaia, V. (1967). Stati o balete [Ballet Articles]. Leningrad: Iskusstvo [in Russian].

Lifar, S. (1952). Traité de chorégraphie [Treaty of choreography]. Paris: Bordas [in French].

Lifar, S. (1994). Stradnye gody. S Diagilevym. Vospominaniia [Suffering years. With Dyagilev. Memories]. Kyiv: Muza [in Russian].

Lifar, S. (1995). Memuary Ikara [Ikar's memories]. Moscow: Iskusstvo [in Russian].

Lyfar, S. (2007). Spohady Ikara [Ikar's memories]. Kyiv: Pulsary [in Ukrainian].

Pastori, Zh.-P. (2013). Serzh Lifar. Krasota ot diavola [Serzh Lifar. Beauty from the devil]. Permian: Knizhnyi mir [in Russian].

Zinych, O. (2009). Mova plastyky v suchasnomu frantsuzkomu baletnomu (plastychnomu) teatri: metamorfozy form rukhu [Language of plastic in modern French ballet (plastic) theater: metamorphosis of forms of motion]. Studii mystetstvoznavchi, 4(28), 80-89 [in Ukrainian].

Zinych, O. (2013). Serzh Lyfar - khoreohraf i khoreoloh: aspekty vzaiemodii muzyky i tantsiu [Serzh Lyfar - choreographer and choreologist: aspects of interaction between music and dance]. Studii mystetstvoznavchi, 3/4, 127-136 [in Ukrainian]. 